\title{
SARS-CoV-2 Infection: General Characteristics and Specific in Dental Practice
}

\author{
Aneta Mijoska $^{1 *}$, Marijan Denkovski ${ }^{2}$, Efka Zabokova-Bilbilovska ${ }^{1}$ \\ ${ }^{1}$ Faculty of Dental Medicine, SS Cyril and Methodius University, Skopje, Republic of Macedonia; ${ }^{2}$ Private Dental Practice \\ "Marijan Denkovski," Kumanovo, Republic of Macedonia
}

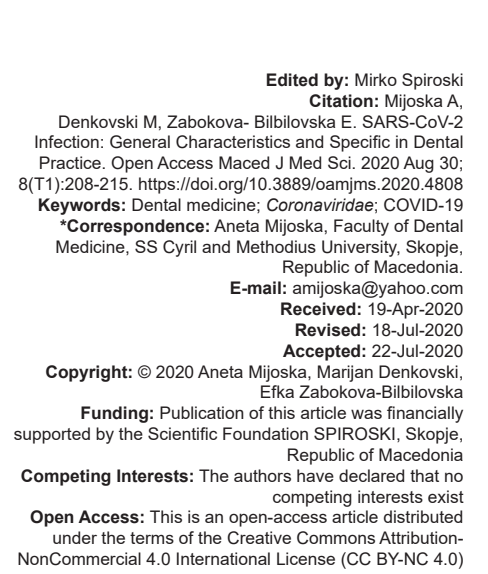

Abstract

The transmission of the coronavirus and possible routes of infection are still unclear. The most common routes of infection in humans are direct transmission through respiratory droplets and saliva when coughing or sneezing and indirect transmission through contaminated surfaces. Most of the infected people after the incubation period have clinical manifestations with mild or moderate respiratory tract infections (RTIs). Physician of dental medicine performs aerosol procedures which transmit the virus directly from healthy people. Oral fluids, blood, conjunctiva, nasal, and oral mucosa are also a source of infection, so they are highly exposed to the virus, much more than other medical staff and therefore it is crucial to establish appropriate protocols and prevention strategies. Under conditions of a declared global pandemic, dentists are advised to stop their work of all cases that are not urgent. If the dental office is one of those that provide the necessary and urgent medical attention, it is necessary to strictly implement control measures to prevent infection. The basic protocols for the operation of the dental offices have been published by the Dental Chamber of Macedonia and they are recommendations regarding the procedures for the maintenance of the hygiene of the medical staff and the working space. Recent experience has shown that dental health-care services are often neglected and inadequately treated in epidemics. Dental workers are particularly exposed to RTIs due to their specific field and mode of operation, so the current experience will prepare them for future challenges.

\section{Introduction}

SARS-CoV-2 is a zoonosis virus that causes illness named "novel coronavirus-infected pneumonia" (NCIP), COVID-19 which the WHO declared as a global pandemic on March 12, 2020 [1], [2]. The virus belongs to the family Coronaviridae of the Nidovirales order and is a non-segmented positive-sense RNA virus [3]. The SARS-CoV-2 (formerly 2019-nCoV) virus, discovered in Wuhan (China), according to phylogenetic analyzes of the viral genome, falls into the genus beta-coronavirus, subgenus Sarbecovirus. 2019-nCoV was more similar to two bat-derived coronavirus strains, bat-SL-CoVZC45 and bat-SL-CoVZXC21, than to known human-infecting coronaviruses [4]. Phylogenetic relationship to RaTG13 is very close which provides evidence that it may have originated in bats [5]. The sequence of the genomic nucleotide discovered in the Rhinolophus affinis bat (Bat SARr-CoV RaTG13) in the Yunnan region of China is $96.2 \%$ identical to the SARS-CoV-2, indicated that the natural host of the virus may be the bat [6].

The SARS-CoV-2 which includes coronaviruses is discovered in humans, bats, and other wild animals [7], [8]. It has the typical appearance of "protein spines" on the membrane and is composed of polyproteins, nucleoproteins, and membrane proteins such as polymerases, proteases, helixes, and other accessory proteins (Figure 1).

Two types of the SARS-CoV-2 major $L(70 \%)$ and minor $S(30 \%)$ were defined, and although the $L$ type was derived from the $S$ type, $L$ is more prevalent, has a higher transmission rate and might be more aggressive than the $S$ type due to the potentially higher transmission and replication rates [9]. The S-protein of the virus introduced into the human body binds to the host receptor, the so-called angiotensin-converting enzyme 2 (ACE-2), enters the target non-immune cells of the respiratory tract, intestinal epithelial, endothelial, kidney cells, cerebral neurons, and immune cells such as alveolar monocytes and macrophages. The pronounced affinity between the virus and the receptors indicates that populations with higher ACE-2 expression are more susceptible to the virus [10]. The symptoms of COVID-19 infection appear after the incubation period as systemic and respiratory disorders dependent on the age and status of the patient's immune system [11]. A recent study showed median incubation period 4 days, median age 47 years and fever and cough presented as most common symptoms [5]. 
The present study aimed to present a general characteristics and specifics of the novel SARS-CoV-2 infection in the dental practice.

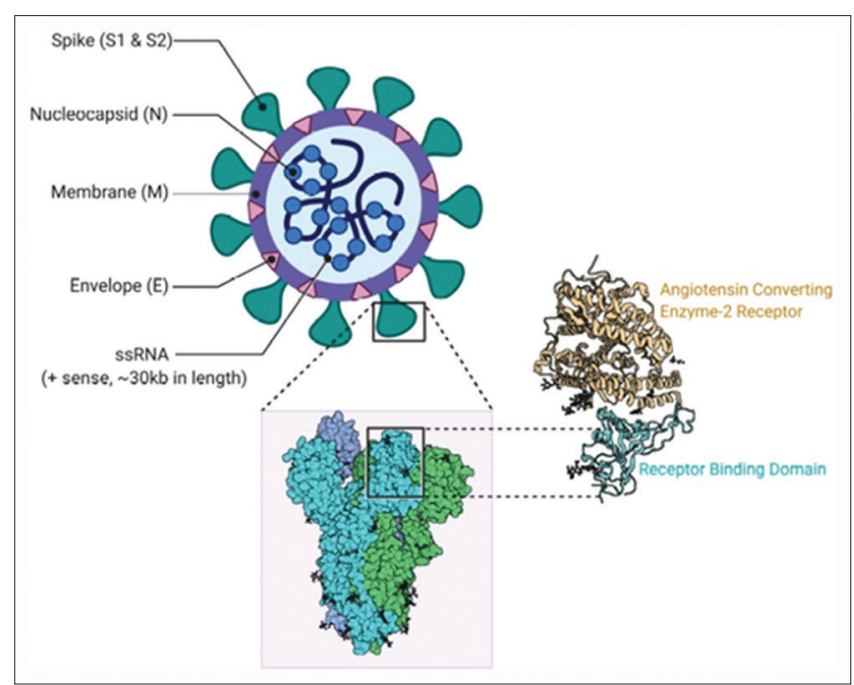

Figure 1: SARS-CoV 2 Structure. (Adapted by: Cascella M, Rajnik M, Cuomo A, et al. Features, Evaluation and Treatment Coronavirus (COVID-19). StatPearls Publishing; 2020. Available from: https:// www.ncbi.nlm.nih.gov/books/NBK554776/.)

\section{Transmission of SARS-CoV-2}

Transmission of the SARS-CoV-2 and possible routes of infection are still unclear. The most common routes of infection are a direct transmission from human to human through respiratory droplets and saliva (Figure 2), when coughing or sneezing, transmitting the virus from person to person and contact transmission when in contact with the oral, nasal, and ocular mucous membranes [12], [13]. Indirect contact transmission is made possible through contaminated surfaces (metal, glass, and plastic) on which the virus can remain for several days, and they may be transferred to the hands of the patients and health-care providers. Various environmental factors such as temperature, humidity, ventilation, and virus amount influence this type of transmission [14]. Serological detection of the

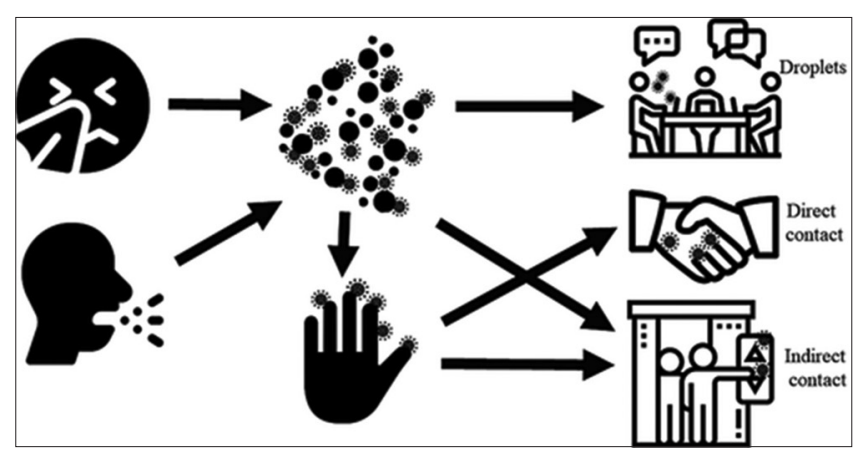

Figure 2: Drivers of transmission of coronavirus (COVID-19) infection consist of short-range, large-droplet transmission $(>5 \mu \mathrm{m}$ in diameter, traveling $<1 \mathrm{~m}$ ); close, unprotected, direct contact; and indirect contact with contaminated surfaces (Adapted by: Cancer cytopathology. 2020;128(5):309-316) virus in oral, anal swabs, and blood samples provides cautionary warning that SARS-CoV-2 from the infected patients can potentially shed the pathogen through respiratory, fecal-oral, or body fluid routes [15].

The virus is present in aerosols for up to 3 $\mathrm{h}$ after emission and has been identified on surface such as cardboard after $24 \mathrm{~h}$, plastic and steel after 2-3 days [16]. Examination of the stability of the virus on contaminated surfaces in experimental conditions showed a large decrease in titer and viability (from 103.7 to $100.6 \mathrm{TCID} 50 / \mathrm{ml} /$ medium) after $72 \mathrm{~h}$ on plastic and $48 \mathrm{~h}$ on stainless steel (Table 1). Unlike previous forms of coronavirus, asymptomatic individuals infected with COVID-19 can transmit the infection through aerosols and objects without becoming ill or before developing symptoms of the disease, which may explain the pandemic course of the infection [17].

Several factors affect how long the virus can survive in the air, most notably the size of the droplets as well as some external influences. Large drops quickly fall to the surface, while smaller ones can stay in the air for a while, and air movement and ventilation can reduce their concentration and remove them from the room. To determine the distribution of SARS-CoV-2 in hospital wards in Wuhan, China, a study testing the air and surface samples showed contamination was greater in intensive care units than general wards, and the virus was widely distributed on floors, computer mice, trash cans, and sickbed handrails and was detected in air $\approx 4$ $\mathrm{m}$ from patients [18]. The presence of the virus on the protective equipment of the medical staff was lower, but it was also present on the sleeves, gloves, and masks, which indicates the need for proper removal of medical protective equipment from medical facilities and disinfection [19]. Although the exact mode of entry of the virus into the human body is not yet known, the mechanism is thought to be similar to that of SARS$\mathrm{CoV}$, where the first target cells are the receptors on the epithelial cells of the salivary ducts [20]. The upper respiratory tract is covered by the epithelial cells which possess the receptors in large numbers, and once they enter the human body, the virus binds to them [21].

\section{Clinical manifestations of COVID-19}

The mean incubation or the asymptomatic period in infected persons usually lasts 3-9 days after the infection, but in some cases the symptoms appear after 24 days [22]. It is estimated that about $44 \%$ of transmission of infection occurred before any

Table 1: Medium survival time of the virus on different surfaces

\begin{tabular}{lll}
\hline Surface & Objects & Survival time \\
Metal & Door handles, cutlery, jewelry & 3 days \\
Plastic & Bottle, buttons, doorknob, seats & $2-3$ days \\
Glass & Window, cup, mirror & $4-5$ days \\
Paper & Books, newspaper & 5 days \\
Wood & furniture, parquet & 4 days \\
Food & Fruit and vegetables & There is no presence \\
Water & Bottled, tap & There is no presence \\
\hline
\end{tabular}


symptom arose [23]. Clinical manifestations are from asymptomatic to fatal pneumonia, and COVID-19 is now classified in four levels based on the severity of symptoms: Mild, moderate, severe, and critical [24]. Most of the infected persons have a mild clinical presentation with moderate respiratory symptoms such as fever, dry cough, and fatigue, while rhinorrhea, nasal congestion, sore throat, or myalgia are less common. Occasionally, non-respiratory symptoms such as palpitation, diarrhea, or headache precede respiratory symptoms [25]. Symptoms of developing a severe clinical picture include shortness of breath, persistent chest pain, or pressure, and livid color of the lips or face, and these individuals need to be treated in a hospital facilities [26]. In some severe cases, the disease rapidly progressed to acute respiratory distress syndrome, septic shock, refractory metabolic acidosis, and coagulation disorder, eventually leading to death [27]. Complications such as pneumonia, hypoxia, secondary infection, multiple organ failure with thromboembolism, gastrointestinal (GI) bleeding, polyneuropathy, and myopathy were the cause of prolonged hospitalization or the fatal outcome of the disease. In these individuals, the laboratory findings showed high erythrocytes count and sedimentation rate, higher D-dimers and prothrombin time, leucopenia, and lymphopenia in the peripheral blood flow [28]. Middle-aged and elderly patients with underlying chronic diseases are susceptible to respiratory failure and may have a poorer prognosis [29]. Hypertension, cardiovascular diseases, diabetes, chronic respiratory diseases, or malignancy are common comorbidities and risk factors for developing a more severe form of COVID-19 [30].

\section{Diagnostics and therapy of COVID-19}

Diagnostics of the disease is made by collecting a sample swab from the respiratory tract. A nasopharyngeal swab is best for detecting the virus RNA using a reversible polymer chain reaction (RT-PCR), and an oropharyngeal or nasal sample can also be used. At least 11 nucleic-acid-based methods and eight antibody detection kits have been approved in China by the National Medical Products Administration (NMPA) for detecting SARS-CoV-2 [31]. However, RT-PCR is the most predominantly used method for diagnosing COVID-19 using the upper or lower respiratory samples. The United States Centers for Disease Control and Prevention (CDC) uses a one-step real time RT-PCR (rRT-PCR) assay, which provides quantitative information on viral loads, to detect the presence of SARS-CoV-2 [32]. The ECDC (European Centre for Disease Prevention and Control) and the WHO (World Health Organization) recommend diagnosing the disease with a molecular test that detects the virus, but to expand the testing capacity, the use of rapid antigen tests has been approved [33]. The decision if someone should be tested is based on clinical and epidemiological data, PCR testing of asymptomatic or mildly symptomatic contacts is considered for individuals who have had contact with a COVID-19 [34].

There is still no specific therapy or vaccine to protect against the disease, and people with severe clinical symptoms use many drugs, the effectiveness of which has not yet been clinically proven. The method of physical distancing and isolation to avoid direct interpersonal contacts, the use of protective masks and disposable gloves seems to be the only effective measure to prevent the spread of the disease and the possibility of so-called flattening of the epidemiological curve.

\section{SARS-CoV-2 Infection in the Dental Practice}

\section{Infection routes}

The presence of the virus in high concentrations in the saliva of infected individuals is the cause of possible direct human-to-human transmission of the infection, but further contact with blood and other body fluids possess an additional risk of transmission. Dentists and other health-care providers who perform aerosol procedures can transmit the virus directly from healthy people or people who have not yet developed symptoms [8]. Dental aerosols are created from dental rotary instruments and ultrasound instruments, so droplets sprayed into the air and can contaminate the clinical environment and this is most important concern in dental clinics [35]. The heavier particles $(>50 \mu \mathrm{m})$ of the aerosols quickly fall onto the surface, while the lighter ones remain present in the air for a longer time, could be inhaled and cause COVID-19 infection during dental intervention itself (Figure 3). Oral fluids, blood, conjunctiva, nasal, and oral mucosa are also source of infection in both modes of transmission not only through droplets or aerosols that contain the virus when people speak or cough without the masks but also through contaminated instruments and surfaces in the office [21]. In its report, American Dental Organization (ADA) points out that dental workers are highly exposed to the virus, much more than other

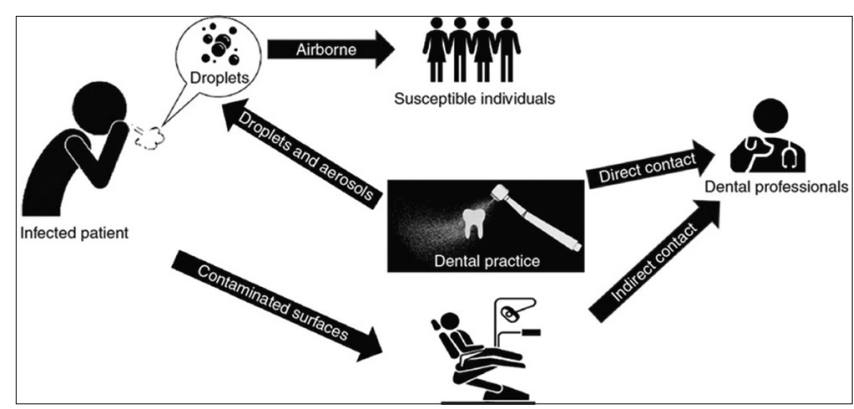

Figure 3: Transmission of the virus in dental practice (Adapted by: Int J Oral Sci 2020;12(1):9. DOI: 10.1038/s41368-020-0075-9) 
medical staff and general practitioners, and therefore it is crucial to establish appropriate protocols and prevention strategies. ADA Interim Guidance for Management of Emergency and Urgent Dental Care use algorithms presenting interim guidance for triaging, screening, and minimizing transmission risks during the time of COVID19 pandemic, by the latest recommendations from health-care agencies [36].

\section{Infection control and prevention in dentistry}

Under conditions of a declared global pandemic, dentists around the world were advised to stop their regular work in the practice for all cases that are not urgent (conservative and surgical) for at least few weeks or as long as there is a risk. It was also necessary to stop not only the work of dental laboratories but also the Faculties of Dental Medicine, because students are a population that due to its exposure and wide range of social contacts can be a potential source of infection. The reasons for taking these measures are primarily not only the high exposure of dental workers to the SARS-CoV-2 due to the nature of the work itself but also the possibility of contamination, transfer, and spread of infection in dental offices [37], [38]. According to Occupational Safety and Health Administration methodology, which evaluates data on workers exposure risk levels, dental practitioners routinely perform several aerosol-generating procedures exposing both clinicians and patient to the risk of infection [39]. Producing and inhalation of the saliva aerosols by infected patients can be considered as virus transmission route, which implicate the importance of making dental practice safe from such risks [40].

If the dental office is one of those that provide the necessary and urgent medical attention, it is necessary to strictly implement control measures to prevent infection. The first contact with the patient should be by telephone, video conference, or text message so that the most appropriate screening and triage can be performed. If more patients are admitted to the office during a day, it is necessary to provide sufficient time between each intervention for ventilation and disinfection, and the therapeutic procedures that create aerosols should be scheduled at the end of working hours and performed with the least necessary assistance staff. Health-care providers who have had close and prolonged contact with infected patients at a health facility should undergo testing for even mild symptoms of the disease, along with supporting staff [41].

The first step before admitting patients should always be to measure the body temperature with a noncontact thermometer on the forehead and then conduct an epidemiological screening survey with a questionnaire. The questions refer to the possible presence of fever in the past 14 days, the presence of respiratory symptoms such as coughing and shortness of breath and epidemiological issues for trips to risky areas, contact with sick or suspicious persons, etc. If the patient answers all the questions in the negative and has a body temperature lower than 37.5 degrees, the dentist can treat him by applying all the necessary protection measures. The basic protocols for the operation of the dental offices during the pandemic in Republic of Macedonia have been published by the Dental Chamber of Macedonia (March 14, 2020) and they were recommendations regarding the procedures for the maintenance of the hygiene of the medical staff and the working space [42]. As a result of the exceptional effort and intensive communication between the Dental Chamber of Macedonia, The Ministry of Health of Republic of Macedonia and the Commission for Infectious Diseases, a decision was made to re-adapt the dental health system for its maximum functioning in emergency conditions and epidemics. The Chamber also defines the "List of Emergency Dental Procedures" for all citizens to have had access to the necessary and urgent dental service care.

\section{Working with Suspect Case, Probable Case, and Confirmed Case of COVID-19}

All suspected, probable, and confirmed cases of COVID-19 in Republic of Macedonia should be treated in the COVID center at St Panteleymon University Dental Clinic, Republic of Macedonia. No First patients were already treated in the specialized center, they were all without any symptoms of the disease, diagnosed and sent in to the home self-isolation. The therapeutic procedures were according the protocols with taking care of all the preventive and after treatment procedures. COVID-19 positive or suspected patients were treated yet, but working protocols and guidance for working of the dental offices are according recommendations by Dental Chamber of Macedonia, considering the WHO recommendation for personal protective equipment (PPE) when working with aerosol-generating procedures and treatments [43].

\section{Protocols for Patients Requiring Emergency Intervention}

Patients in the dental office should be admitted after screening and an epidemiological questionnaire and consent. To reduce the possibility of virus transmission, it is necessary to avoid interventions that create aerosols and use cofferdam whenever necessary, because it allows a significant reduction in aerosol transmission up to $70 \%$ [44]. Patients need to perform hand washing with soap and disinfection with an alcohol-based product over $60 \%$ or with disinfectant tissues [45]. The presence of high concentrations of the virus in saliva can be reduced, though not eliminated [46]. Preoperational rinse of the 
oral cavity with antimicrobial solution (1\% Hydrogen peroxide or $0.2 \%$ Povidone-iodine) is suggested protocol before each dental intervention [47].

\section{PPE}

All patients have to be treated with high alert as signs and symptoms may not appear at early infected cases. The operator and other dental staff in the dental office must use additional PPE when working with each patient, and these are usually protective coats or disposable gowns. Particular attention should be paid to the protection of the face and head, disposable hats, goggles, shields for protection of the face, disposable filtering face masks-aspirators FFP3 (or FFP2 and FFP1) masks, N-95 masks and disposable protective gloves are necessary to wear (Figure 4). Research has shown the possibility of infecting health-care personnel due to improper disposal of PPE [48].

\section{Clinical Protocols}

Restrictions of all aerosol procedures for pain relieve and infection control are highly recommended. When a patient is diagnosed with caries leading to

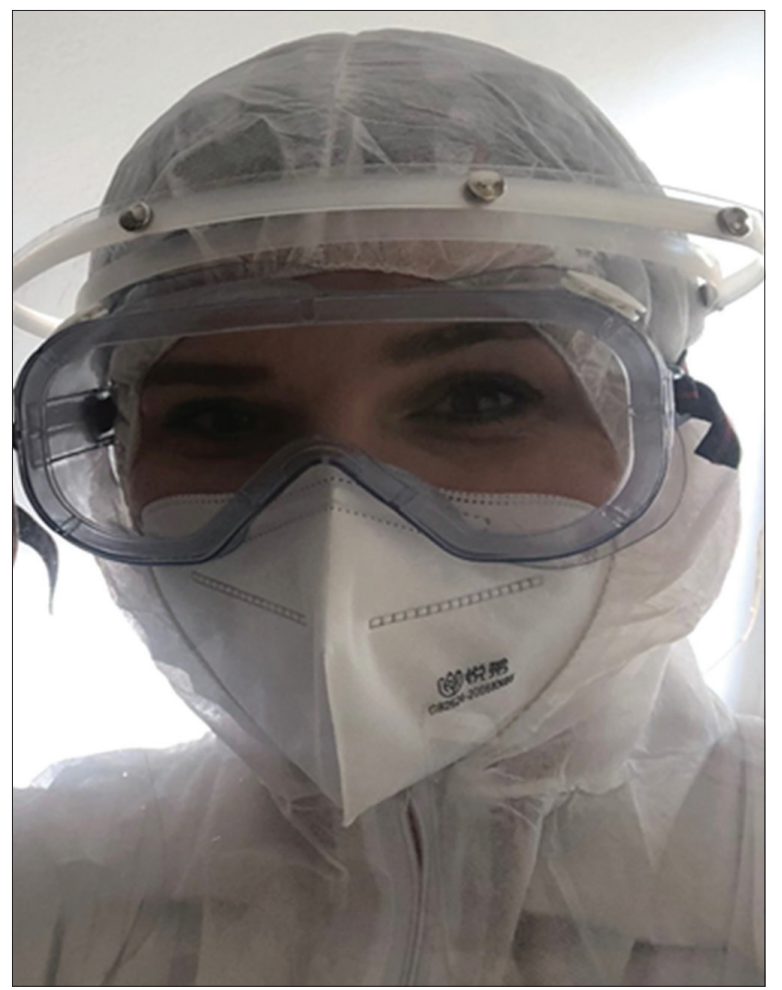

Figure 4: Personal protective equipment at the St Panteleymon University Dental Clinic, Skopje, Republic of Macedonia irreversible pulpitis, a condition accompanied by severe and intense pain, after the application of local anesthesia it is necessary to place a rubber dam and possibly use chemical-mechanical means to evacuate the carious mass and devitalize the pulp [49]. However, if there is a need for use of rotating instruments for trepanation of the tooth, it is advisable to use anti-retraction high-speed dental handpiece to reduce the backflow with an anti-return valve that can prevent aspiration and return of debris and liquids that are created during the procedure [50]. The use of inappropriate techniques and instruments during interventions can lead to additional bacterial and viral contamination of the air and hose of the dental unit and thus the possibility of causing a cross-infection. Standard saliva aspiration systems can be clogged, so it is recommended to use intra/extra-oral suctions evacuators with a larger volume [51].

As the most common X-ray technique, small retroalveolar imaging may stimulate increased salivary secretion and cough, and it is therefore recommended that extraoral imaging (panoramic radiography or Cone-Beam Computed Tomography) be performed whenever possible [52]. Special attention should be paid to the auxiliary and waiting rooms where patients can disperse infectious material by coughing or sneezing. It is necessary to remove all newspapers and similar contents and regularly disinfect all surfaces, by placing alcohol-based disinfectants in clearly visible places and the availability of masks to protect patients. Air ventilation systems in the workplace should be disinfected more often than usual [53]. Rooms with natural ventilation should be ventilated frequently and regularly, and a negative air pressure system should be used in operating rooms.

\section{Disinfectants in the Dental Offices}

Due to the already proven presence of human coronaviruses on the instruments and objects around the room at room temperature for several days, taking the most appropriate strict disinfection measures is inevitable during and after daily work in the offices. Water and detergents in combination with common disinfectants should be used to clean operationale and areas at high risk for the presence of the virus with $0.05 \%$ Sodium Hypochlorite diluted with water (1 $\mathrm{g} / \mathrm{L})$ [54]. For disinfection of smaller areas, $70 \%$ Ethanol (Ethyl alcohol) can be used, which after $1 \mathrm{~min}$ of exposure showed a significant reduction in the vitality of coronaviruses and the effect on SARSCoV-2 is assumed to be similar [54]. Ethyl alcohol (78-95\%), 2-propanol (70-100\%), a combination of 45\% 2-propanol with 30\% 1-propanol, glutaraldehyde 
$(0.5-2.5 \%)$, formaldehyde $(0.7-1 \%)$, and Povidoneiodine $(0.23-7.5 \%)$ eliminate virus infectivity by 4 log or more [55]. Hydrogen peroxide (hydrogen) shows effect at a concentration of $0.5 \%$ and an exposure period of $1 \mathrm{~min}$ [56]. Use of Class B autoclave to sterilize all instrument including high-speed hand pieces with spore tests at least one weekly is highly recommended [54]. Decontamination of the hands of health personnel is of great importance and the recommendation is to perform it with alcoholic wipes (80\% Ethanol or $75 \%$ 2-propanol) immediately after removing the gloves [57].

\section{Management of Medical Waste and Disposable Protective Equipment}

Instruments and disposable items should be recycled, cleaned, sterilized, and properly stored following the disinfection and sterilization procedures of dental instruments [58]. Medical and domestic waste generated by the treatment of patients with suspected or confirmed COVID-19 infection is considered contagious medical waste to which special protocols prescribed by the competent institutions.

\section{Conclusion}

Recent experience has shown that dental health-care services are often neglected and inadequately treated in situations when such or similar epidemics occur. State institutions and relevant public health organizations should seriously consider finding ways to respond appropriately and promptly, primarily to the form in which dental health care will have to meet the challenges of these times. There is some uncertainty in all other segments of social action as the world encounters this new pathogen, potentially lethal and with a unique way of inter-personal transmission. We are still faced with unknown regarding immune response, origin, disease dynamics, and therapy. What is undoubtedly of great importance is the protection and strengthening of health systems and health workers at all levels, because they are at the forefront of the fight, and preserving their health is of great importance. Dental workers are particularly exposed to respiratory infections due to their specific field and mode of operation, and understanding routes of transmission of COVID-19 may have positive outcome in prevention of the infection. Current experiences will raise the level of readiness, reduce the risk and enable future challenges to be addressed as quickly as possible with minimal losses in material and human resources.

\section{References}

1. World Health Organization. Coronavirus Disease 2019 (COVID19) Situation Report-71. Available from: https://www.who. int/emergencies/diseases/novel-coronavirus-2019/situationreports. [Last accessed on 2020 Mar 20].

2. Zhu N, Zhang D, Wang W, Li X, Yang B, Song J, et al. A novel coronavirus from patients with pneumonia in China, 2019. N Engl J Med. 2020;382(8):727-33.

PMid:31978945

3. Baymakova M, Popov GT. Coronaviruses: SARS-CoV, MERSCoV and SARS-CoV-2 (formerly 2019-nCoV). MD Bulgaria. 2020;17(1):95-102. https://doi.org/10.21203/rs.3.rs-20476/v2

4. Lu R, Zhao X, Li J, Niu P, Yang B, Wu H, et al. Genomic characterisation and epidemiology of 2019 novel coronavirus: Implications for virus origins and receptor binding. Lancet. 2020;395(10224):565-74.

PMid:32007145

5. Zhou P, Yang XL, Wang XG, Hu B, Zhang L, Zhang W, et al. A pneumonia outbreak associated with a new coronavirus of probable bat origin. Nature. 2020;579(7798):270-3. https://doi. org/10.1038/s41586-020-2012-7

\section{PMid:32015507}

6. Tan WJ, Zhao X, Ma XJ, Wang W, Niu P, Xu W, et al. A nove coronavirus genome identified in a cluster of pneumonia casesWuhan, China 2019-2020. China CDC Wkly. 2020;2(4):61-2. https://doi.org/10.46234/ccdcw2020.017

7. Tang $\mathrm{X}, \mathrm{Wu} \mathrm{C}$, Li $\mathrm{X}$, Song $\mathrm{Y}$, Yao $\mathrm{X}$, Wu $\mathrm{X}$, et al. On the origin and continuing evolution of SARS-CoV-2. Natl Sci Rev. 2020;7(6):1012-23

8. Peng X, Xu X, Li Y, Cheng L, Zhou X, Ren B. Transmission routes of 2019-nCoV and controls in dental practice. Int J Oral Sci. 2020;12(1):9. https://doi.org/10.1038/s41368-020-0075-9

9. Magrone $\mathrm{T}$, Magrone M, Jirillo E. Focus on receptors for coronaviruses with special reference to angiotensin-converting enzyme 2 as a potential drug target-a perspective. Endocr Metab Immune Disord Drug Targets. 2020;20(6):807-11. PMid:32338224

10. Guo Y, Korteweg C, McNutt MA, Gu J. Pathogenetic mechanisms of severe acute respiratory syndrome. Virus Res. 2008;133(1):412. https://doi.org/10.1016/j.virusres.2007.01.022 PMid:17825937

11. Guan W, Ni ZY, Hu Y, Liang WH, Ou CQ, He JX, et al. Clinical characteristics of coronavirus disease 2019 in China. N Engl J Med. 2020;382:1708-20.

12. Rothana HA, Byrareddy SN. The epidemiology and pathogenesis of coronavirus disease (COVID-19) outbreak. J Autoimmun. 2020;109:1024333. https://doi.org/10.1016/j.jaut.2020.102433 PMid:32113704

13. Whang $Z, X u X$. Single-cell RNA expression profiling of ACE2, the putative receptor of Wuhan 2019-nCov. Cells. 2020;9(4):920. https://doi.org/10.3390/cells9040920

14. Lu CW, Liu XF, Jia ZF. 2019-nCoV transmission through the ocular surface must not be ignored. Lancet. 2020;395(10224):e39. https://doi.org/10.1016/s0140-6736(20)30313-5 PMid:32035510

15. Zhang W, Du RH, Li B, Zheng XS, Yang XL, Hu B, et al. Molecular and serological investigation of $2019-n C o V$ infected patients: Implication of multiple shedding routes. Emerg Microbes Infect. 2020;9:386-9. https://doi.org/10.1080/22221751.2020.1729071 PMid:32065057

16. Van Doremalen N, Bushmaker T, Morris DH, Holbrook MG, Gamble A, Williamson BN, et al. Aerosol and surface stability 
of HCoV-19 (SARS-CoV-2) compared to SARS-CoV-1. N Engl J Med. 2020;382(16):1564-7. https://doi.org/10.1056/ nejmc2004973

PMid:32182409

17. To KK, Tsang OT, Yip CC, Chan WH, Wu TC, Chan JM, et al Consistent detection of 2019 novel Coronavirus in saliva. Clin Infect Dis. 2020;71(15):841-3.

PMid:32047895

18. Guo ZD, Wang ZY, Zhang SF, Li X, Li L, Li C, et al. Aerosol and surface distribution of severe acute respiratory syndrome coronavirus 2 in hospital wards, Wuhan, China, 2020. Emerg Infect Dis. 2020;26(7):1583-91. https://doi.org/10.3201/ eid2607.200885

PMid:32275497

19. Rothe C, Schunk M, Sothmann P, Bretzel G, Froeschl G, Wallrauch C, et al. Transmission of 2019-nCoV infection from an asymptomatic contact in Germany. N Engl J Med. 2020;382(10):970-1.

PMid:32003551

20. Liu L, Wei Q, Alvarez X, Wang H, Du Y, Zhu H, et al. Epithelial cells lining salivary gland ducts are early target cells of severe acute respiratory syndrome coronavirus infection in the upper respiratory tracts of rhesus macaques. J Virol. 2011;85:402530. https://doi.org/10.1128/jvi.02292-10

PMid:21289121

21. Chen J. Pathogenicity and transmissibility of 2019-nCoV-a quick overview and comparison with other emerging viruses. Microb Infect. 2020;22(2):69-71. https://doi.org/10.1016/j. micinf.2020.01.004

22. He X, Lau EH, Wu P, Deng X, Wang J, Hao X, et al. Temporal dynamics in viral shedding and transmissibility of COVID-19. Nat Med. 2020;26(5):672-75. https://doi.org/10.3345/cep.2020.00493 PMid:32296168

23. Park SE. Epidemiology, virology, and clinical features of severe acute respiratory syndrome-coronavirus-2 (SARS-CoV-2; coronavirus disease-19). Clin Exp Pediatr. 2020;63(4):119-24. https://doi.org/10.1002/jmv.25748

24. Wang $Y$, Wang $Y$, Chen $Y$, Qin $Q$. Unique epidemiological and clinical features of the emerging 2019 novel coronavirus pneumonia (COVID19) implicate special control measures. J Med Virol. 2020;92(6):568-76. https://doi.org/10.1002/ jmv.25748

PMid:32134116

25. Siordia JA. Epidemiology and clinical features of COVID-19: A review of current literature. J Clin Virol. 2020;127:104357. https://doi.org/10.1016/j.jcv.2020.104357 PMid:32305884

26. Wang D. Clinical characteristics of 138 hospitalized patients with 2019 novel coronavirus-infected pneumonia in Wuhan, China. JAMA. 2020;323(11):1061-9.

PMid:32031570

27. Zheng J. SARS-CoV-2: An emerging coronavirus that causes a global threat. Int J Biol Sci. 2020;16(10):1678-85. https://doi. org/10.7150/ijbs. 45053

PMid:32226285

28. Huang C, Wang Y, Li X, Ren L, Zhao J, Hu Y, et al. Clinical features of patients infected with 2019 novel coronavirus in Wuhan, China. Lancet. 2020;395(10223):497-506.

PMid:31986264

29. Liu K, Fang YY, Deng Y, Liu W, Wang MF, Ma JP, et al. Clinical characteristics of novel coronavirus cases in tertiary hospitals in Hubei Province. Chin Med J (Engl). 2020;133(9):1025-31. https://doi.org/10.1097/cm9.0000000000000744

PMid:32044814
30. Guan WJ, Liang WH, Zhao Y, Liang HR, Chen ZS, Li YM, et al. Comorbidity and its impact on 1590 patients with COVID-19 in China: A nationwide analysis. Eur Respir J. 2020;55(5):2000547. PMid:32217650

31. Udugama B, Kadhiresan P, Kozlowski HN, Malekjahani A, Osborne M, Li VY, et al. Diagnosing COVID-19: The disease and tools for detection. ACS Nano. 2020;14(4):3822-35. https:// doi.org/10.1021/acsnano.0c02624

PMid:32223179

32. Research Use Only Real-time RT-PCR Protocol for Identification of 2019-nCoV; Centers for Disease Control and Prevention. Available from: https://www.cdc.gov/coronavirus/2019-ncov/lab/ rt-pcr-detection-instructions.html. [Last accessed on 2020 Mar 06]. https://doi.org/10.17504/protocols.io.bb3piqmn

33. WHO. Laboratory Testing Strategy Recommendations for COVID-19 Interim Guidance; 2020. Available from: http:// www.C:/Users/Admin/Downloads/WHO-COVID-19-laboratory2020.5-eng.pdf. [Last accessed on 2020 Mar 20].

34. World Health Organization. Laboratory Testing for Coronavirus Disease (COVID-19) in Suspected Human Cases Interim Guidance. Geneva: World Health Organization; 2020.

35. Cleveland JL, Gray SK, Harte JA, Robison VA, Moorman AC, Gooch BF. Transmission of blood-borne pathogens in US dental health care settings: 2016 update. J Am Dent Assoc. 2016;147(9):729-38.

PMid:27233680

36. ADA Interim Guidance for Minimizing Risk of COVID-19 Transmission; 2020. Available from: https://www.ada.org/ / media/CPS/Files/COVID/ADA_COVID_Int_Guidance_ Treat_Pts.pdf?utm_source=adaorg\&utm_medium $=$ covidresources-Ip\&utm_content $=c \mathrm{c}$-pm-ebd-interim-response\&utm campaign=covid-19. https://doi.org/10.4060/ca8660en [Last accessed on 2020 Mar 25].

37. Gamio L. The Workers Who Face the Greatest Coronavirus Risk. Available from: https://www.nytimes.com/interactive/2020/03/15/ business/economy/coronavirus-worker-risk. $\mathrm{html}$ ?action=click\&module=Top+Stories\&pgtype=Homepage [Last accessed on 2020 Mar 25].

38. Prati C, Pelliccioni GA, Sambri V, Chersoni C, Gandolfi MG. COVID-19: Its impact on dental schools in Italy, clinical problems in endodontic therapy and general considerations. Int Endod J. 2020;53(5):35-40. https://doi.org/10.1111/iej.13291

PMid:32277770

39. Peditto M, Scapellato S, Marcianò A, Costa P, Oteri G. Dentistry during the COVID-19 epidemic: An Italian workflow for the management of dental practice. Int J Environ Res Public Health 2020;17(9):3325. https://doi.org/10.3390/ijerph17093325 PMid:32403248

40. Sabino-Silva R, Jardim AC, Siqueira WL. Coronavirus COVID-19 impacts to dentistry and potential salivary diagnosis. Clin Oral Invest. 2020;24(4):1619-21. https://doi.org/10.1007/ s00784-020-03248-x

PMid:32078048

41. Koh D. Occupational risks for COVID-19 infection. Occup Med (Lond). 2020;70(1):3-5.

PMid:32107548

42. Available from: https://www.skm.mk/протоколи-за-работа-во време-на-пандем. [Last accessed on 2020 Mar 15].

43. WHO. Rational Use of Personal Protective Equipment for Coronavirus Disease (COVID-19). Interim Guidance; 2020. Available from: http://www.Who.int. [Last accessed on 2020 Mar 17].

44. Napimoga MH, Freitas AR. Dentistry vs severe acute respiratory syndrome coronavirus 2. How to face this enemy. Rev Gaúch Odontol. 2020;68:2020-110. https://doi. 
org/10.1590/1981-863720200001120200034

45. Adhikari SP, Meng S, Wu YJ, Mao YP, Ye RX, Wang QZ, et al. Epidemiology, causes, clinical manifestation and diagnosis, prevention and control of coronavirus disease (COVID-19) during the early outbreak period: A scoping review. Infect Dis Poverty. 2020;9(1):29. https://doi.org/10.1186/s40249-020-00646-x PMid:32183901

46. Challacombe SJ, Kirk-Bayley J, Sunkaraneni VS, Combes J. Povidone iodine. Br Dent J. 2020;228(9):656-7. https://doi. org/10.1038/s41415-020-1589-4

PMid:32385428

47. Tsuda S, Soutome S, Hayashida S, Funahara M, Yanamoto S, Umeda M. Topical povidone iodine inhibits bacterial growth in the oral cavity of patients on mechanical ventilation: A randomized controlled study. BMC Oral Health. 2020;20(1):62. https://doi. org/10.1186/s12903-020-1043-7

PMid:32093667

48. Spagnuolo G, De Vito D, Rengo S, Tatullo M. COVID-19 Outbreak: An Overview on Dentistry. Int J Environ Res Public Health. 2020;17(6):2094. https://doi.org/10.3390/ ijerph17062094 PMid:32235685

49. LiR, Leung K, Sun F, Samaranayake L. Severe acute respiratory syndrome (SARS) and the GDP. Part II: Implications for GDPs. Br Dent J. 2004;197(3):130-4. https://doi.org/10.1038/ sj.bdj.4811522

PMid: 15311240

50. Cirillo N. COVID-19 outbreak: Succinct advice for dentists and oral healthcare professionals. Clin Oral Investig. 2020;24(7):2529-35. https://doi.org/10.1007/s00784-020-03323-3 PMid:32430776

51. Fini MB. What dentists need to know about COVID-19. Oral Oncol. 2020;105:104741. https://doi.org/10.1016/j. oraloncology.2020.104741 PMid:32380453

52. Vandenberghe $B$, Jacobs R, Bosmans H. Modern dental imaging: A review of the current technology and clinical applications in dental practice. Eur Radiol. 2010;20(11):263755. https://doi.org/10.1007/s00330-010-1836-1

PMid:20544352

53. Casanova LM, Jeon S, Rutala WA, Weber DJ, Sobsey MD. Effects of air temperature and relative humidity on coronavirus survival on surfaces. Appl Environ Microbiol. 2010;76(9):2712-7. https://doi.org/10.1128/aem.02291-09 PMid:20228108

54. Siddharta A, Pfaender S, Vielle NJ, Dijkman R, Friesland M, Becker B, et al. Virucidal activity of recommended formulations against enveloped viruses, including Zika, Ebola, and emerging coronaviruses. J Infect Dis. 2017;215(6):902-6. https://doi. org/10.1093/infdis/jix046

PMid:28453839

55. Kampf G, Todt D, Pfaender S, Steinmann E. Persistence of coronaviruses on inanimate surfaces and their inactivation with biocidal agents. J Hosp Infect. 2020;104(3):246-251. https://doi. org/10.1016/j.jhin.2020.01.022 PMid:32035997

56. Meng L, Hua F, Bian Z. Coronavirus disease 2019 (COVID-19): Emerging and future challenges for dental and oral medicine. J Dent Res. 2020;22(3):452. https://doi. org/10.1177/0022034520914246 PMid:32162995

57. Fung IC, CairncrossS. Effectiveness ofhandwashing in preventing SARS: A review. Trop Med Int Health. 2006;11(11):1749-58. https://doi.org/10.1111/j.1365-3156.2006.01734.x PMid: 17054756

58. Yu H, Sun X, Solvang WD, Zhao X. Reverse logistics network design for effective management of medical waste in epidemic outbreaks: Insights from the coronavirus disease 2019 (COVID-19) outbreak in Wuhan (China). Int J Environ Res Public Health. 2020;17(5):1770. https://doi.org/10.3390/ ijerph17051770

PMid:32182811 